\title{
EFFECTS OF POPULATION DENSITY AND HOST AVAILABILITY ON THE MIGRATION PROCESS OF BROWN PLANTHOPPER FED USING SUSCEPTIBLE AND RESISTANT RICE VARIETIES
}

\author{
PENGARUH KEPADATAN POPULASI DAN KETERSEDIAAN PAKAN TERHADAP PROSES \\ MIGRASI WERENG BATANG COKELAT PADA PADI VARIETAS RENTAN DAN TAHAN
}

\author{
Imam Habibi ${ }^{1) *}$, Witjaksono ${ }^{1)}$, \& Arman Wijonarko ${ }^{1)}$ \\ ${ }^{1)}$ Department of Crop Protection, Faculty of Agriculture, Universitas Gadjah Mada \\ Jln. Flora 1, Bulaksumur, Sleman, Yogyakarta 55281 \\ *Corresponding author.E-mail: imamhabibi87@yahoo.com
}

\begin{abstract}
Brown planthopper, Nilaparvata lugens Stal. (Hemiptera: Delphacidae), is an important pest of rice. This pest can cause hopperburn and field failure. This research aimed to determine the effects of population density and host availability on migration of $N$. lugens. The criteria used to justify the effects of host availability and population density on migration of $N$. lugens were based the hardness and tannin tests of the rice stems, fecundity of $N$. lugens, and the life cycle of $N$. lugens. The research was conducted under the temperature of $29.42^{\circ} \mathrm{C}$ with relative humidity of $61 \%$ and Light 12: Dark 12 times, using ten pairs of $N$. lugens brachypterous (F0 constant) and then was added with five male adults on fifth days after the first infestation (F0 changed). The varieties used were IR64, as a resistant variety, and Ketan Lusi, as a susceptible variety. The results showed that the adding of the macropterous males did not affect the number of macropterous, because of that has been preplanned by the F0. Therefore, the percentage of existing macropterous was $51-52 \%$.
\end{abstract}

Keywords: brachypterous, macropterous, Nilaparvata lugens, percentage of migration, population density

\section{INTISARI}

Wereng Batang Cokelat (WBC) merupakan salah satu hama tanaman padi yang sangat penting. Kerusakan parah dapat menyebabkan hopperburn dan puso (gagal panen). Tujuan penelitian ini adalah mengetahui pengaruh kepadatan populasi dan tanaman inang sebagai tempat migrasi WBC. Parameter yang dikaji untuk mengetahui pengaruh kepadatan populasi WBC dan tanaman inang tempat migrasi WBC berdasarkan tingkat kekerasan dan kandungan tanin batang tanaman padi, fekunditas WBC, dan siklus hidup WBC. Penelitian ini dilakukan pada temperatur $29.42^{\circ} \mathrm{C}$ dengan kelembapan relatif $61 \%$ dan durasi siang hari 12 jam: durasi malam hari 12 jam. Metode yang dilakukan adalah dengan menggunakan 10 pasang imago WBC brakhiptera (F0 konstan), kemudian dilakukan penambahan 5 ekor imago jantan pada hari kelima setelah infestasi awal (F0 diubah). Varietas padi yang digunakan yaitu padi varietas IR64 sebagai varietas tahan dan ketan Lusi sebagai varietas rentan. Hasil penelitian menunjukkan bahwa penambahan imago jantan makroptera tidak berpengaruh terhadap jumlah keturunan makroptera yang dihasilkan, karena imago (F0) telah merencanakan terlebih dahulu keturunan yang akan dihasilkan. Oleh karena itu, persentase terbentuk keturunan imago makroptera berkisar antara 51-52\%.

Kata kunci: brakhiptera, kepadatan populasi, makroptera, Nilaparvata lugens, persentase migrasi

\section{INTRODUCTION}

In Indonesia, rice is an important food commodity. In 2014, there was an area of 14.30 million hectares with production of 71.33 million tons of GKG (Gabah Kering Giling) (Sembiring, 2015). One year after that, BPS (Statistics Indonesia) estimated that on 2 November 2015, rice production would be 74.99 million tons of milled dry rice $(\mathrm{GKG})$ or increasing of $5.84 \%$ than the last year. Hence, it was presumed that will be a surplus of rice production in Indonesia (Soim, 2016). The resistant variety to $N$. lugens mostly cultivated in Indonesia is IR64. Beside of that, Ketan variety (susceptible variety) is also cultivated to make flour in the manufacture of cakes, bread, baby food and others. The Ketan variety mostly cultivated by farmers is Ketan Lusi. The more consumers need flour, the more flour in good quantity and quality is necessitated (Wardani, 2011).

Brown planthopper, Nilaparvata lugens Stal. (Hemitera: Delphacidae), is an important pest of rice. The outbreak of this pest can cause hopperburn. Hopperburn is caused by the dry climate conditions and the rice has not been cultivated all at once (Waspo, 1999). Those condition causes the host of this pest is available all the time. The macropterous (adult winged $N$. lugens) has a role to migrate after the host is unavailable and the brachypterous (adult 
rounded-abdomen $N$. lugens) has a role to produce their offspings. The outbreak of $N$. lugens can cause the migration of this pest to another rice cultivated. Therefore, the research about the migration behaviour of this pest is necessitated. This research was aimed to determine the effects of population density and host availability on the emergence of macropterous offspring of $N$. lugens. The variety of IR64 (as a resistant variety) and Ketan Lusi (as a susceptible variety) were used as host treatment.

\section{MATERIALS AND METHODS}

\section{Nilaparvata lugens Colony}

The initial population of $N$. lugens was collected from Janten Village, Juwiring County, Klaten District, Central Java Province, on September 2014.

\section{Mass Rearing of Nilaparvata lugens}

Mass rearing of $N$. lugens was conducted in the Laboratory of Applied Entomology, Department of Crop Protection, Faculty of Agriculture, Universitas Gadjah Mada, Yogyakarta, and carried out under temperature of $29.42^{\circ} \mathrm{C}$ and relative humidity of $61 \%$, and Light 12: Dark 12 hours. The collected $N$. lugens was reared using seeds of Situbagendit variety germinated in a plastic jar (with $6 \mathrm{~cm}$ in diameter and 9 in height) covered with white cloth on top and and tied with rubber. The freshness of seedlings was maintained daily. The new seedlings were supplied every week or when the seedlings become yellow. Those experiments were repeated until $N$. lugens population reached 13th generation (F13).

\section{Experimental Design}

Treatments. This experiment consisted of two treatments: IR64 as resistant variety and Ketan Lusi as susceptible variety. Treatment was done by put the 10 seedlings of each variety into plastic cups (with $6 \mathrm{~cm}$ in diameter and 9 in height) covered with white cloth on top and tied with rubber. The freshness of seedlings was maintained everyday. Those seedlings were grown until 7 days in aged and used to conduct an experiment. This experiment was consisted of two batches as described below:

Effect of host availability on the migration of Nilaparvata lugens. The first batch was conducted using 10 pairs of brachypterous $N$. lugens put into a plastic cup contained 10 seedlings rice for each variety treatment (first infestation). Each treatment was repeated three times and observed daily to count the number of emerged $N$. lugens adults and to maintain the freshness of seedlings.
Effect of population density on the migration of Nilaparvata lugens. The second batch was employed with the same design as mentioned in the first batch, and the only difference was the addition of five males of macropterous $N$. lugens on fifth day after the first infestation. The criteria used to justify the effects of host availability and population density on migration of $N$. lugens were based on the hardness and tannin tests of the rice stems, fecundity of $N$. lugens, and the life cycle of $N$. lugens.

The hardness and tannin tests of the rice stem. The hardness test of rice stems was conducted at the Laboratory of Food Technology of Agricultural Products, Faculty of Agricultural Technology, Universitas Gadjah Mada, Yogyakarta. The Universal Testing Machine (BDO-FB0.5TS) in Laboratory of Management Process Engineering, Faculty of Agricultural Technology, Universitas Gadjah Mada was used for testing the texture of rice stems. The two rice stems of 7 days old from each variety was used for that test. The quantity of tannin was tested by a spectro-photometer (Spectronic 200 Thermoscientific), in Chemistry and Biochemistry Laboratory of Food and Agriculture Products, Faculty of Agricultural Technology, Universitas Gadjah Mada using 20 grams of rice stems of 7 days old for each variety.

Fecundity of Nilaparvata lugens. Nurbaeti et al. (2010) stated that the oviposition periods of brachypterous and macropterous adults were $3-4$ days and 3-8 days, respectively. Therefore, the fecundity of $N$. lugens was observed on fifth and fourteen days after treatment (first and second batches). Emergence of macropterous adults was began on fifth day and assumed that on fourteen day was the end of laying eggs.

The life cycle of Nilaparvata lugens. The longevity of nymphs and adult $N$. lugens was observed every two days. Each variety treatment used seedlings in aged 7 day with 3 replications. The first nymphs became second nymphs were separated, put into a new plastic cup, fed by new seedlings, and counted their number. This experiment was repeated until fifth nymphs became adults and observed for recording the number of macropterous and brachypterous emerged (as F0).

The life cycle of $N$. lugens was observed when the first nymphs found from each treatment using 10 replications. Each variety treatment used two seedlings 7 days in aged. This parameter was observed by using $\mathrm{F} 1$ of the offsprings produced by F0 from the parameter described before. Longevity for each nymph stadia was observed and their number was counted. After those nymphs became adults, $N$. lugens 
was mated using 10 pairs, and seedlings were supplied to determine when the eggs laid on that. Then the eggs found were counted using a stereo microscope (Olympus series SZ-ST). The number of the new hatched nymphs of those eggs were counted.

The life duration of $N$. lugens adult was observed 5 times. This experiment was conducted using the adults of $F 1$ fed using two seedlings of 7 day in aged for each variety treatment. Mortality of adults was recorded. The freshness of seedlings was maintained daily with added water into the plastic cup.

\section{Data Analysis}

The number of eggs, the number of emerged adults, the number of female brachypterous and macropterous, and the longevity for each stadium were analyzed using independent $\mathrm{t}$-test and $\mathrm{P}=0.05$ by SPSS 16.

\section{RESULTS AND DISCUSSION}

\section{The Hardness Test and the Quantity of Tannin of the Rice Stem}

The hardness of IR64 stems $(19.6 \mathrm{~N})$ was higher than that in Ketan Lusi (10.8 N). Asikin (2006) showed that the harder stem of the rice, the lower damage of rice stem borer. However, the quantity of tannin of IR64 $(0.92 \mathrm{mg} / \mathrm{g})$ was lower than that in Ketan Lusi $(1.21 \mathrm{mg} / \mathrm{g})$. The higher tannin, the more decrease of feeding activity of the insect. This is supported by Debby and Moniharapon (2014) showed that melinjo leaf extract could be used as an antifeedant.

\section{Effect of Host Availability on the Migration of Nilaparvata lugens}

Fecundity of Nilaparvata lugens. The number of eggs produced on IR64 (486.33 eggs) was similar of that in Ketan Lusi (394.67 eggs) $(t=2.011, d f=4$, $\mathrm{P}=0.115$ (Table 1). In addition, the number of nymphs and adults also was similar in IR64 than those in Ketan Lusi. That result might be due to the temperature of the regime in which is relatively higher than the room temperature normally $\left(25^{\circ} \mathrm{C}\right)$. Cannon (1998) reported that agricultural insect pests become more abundant as the increasing of temperature. Zhang et al. (2015) also reported that at $40^{\circ} \mathrm{C}$, the eggs produced by the diamondback moth, Plutella xylostella decreased. Other study (Bale et al., 2002) stated that mostly of the insect have their optimal growth in the warm condition.

The life cycle of Nilaparvata lugens. The number of adults emerged from Ketan Lusi (97\%) was higher than that from IR64 (89\%), probably due to the hardness of rice stem in IR64 was higher than Ketan Lusi. The higher hardness of rice stem, the more difficult for nymphs to absorb the nutrients in those stems for their growth and development. Therefore, it might decreased the survival rate of the nymps to become adults. Previous studies by Serratos et al., 1987; Trumble \& Hare, 1997; Mbata et al., 2009 also reported the same results on different species Sitophilus zeamais, Spodoptera exigua, or Callosobruchus maculatus.

$N$. lugens fed using IR64 (92 males and 15.2 days) produced the male adults of macropterous and their

Table 1. The number of eggs, nymphs and F1 adults of Nilaparvata lugens fed using resistant and susceptible varieties without adding five males of macropterous on F0 population

\begin{tabular}{lcc}
\hline Parameter & \multicolumn{2}{c}{ Variety } \\
\cline { 2 - 3 } & IR64 & Ketan Lusi \\
\hline Number of eggs & $486.33 \pm 39.08 \mathrm{a}$ & $394.67 \pm 23.47 \mathrm{a}$ \\
Number of nymph & & \\
Instar 1 & $285.00 \pm 42.72 \mathrm{a}$ & $224.00 \pm 17.90 \mathrm{a}$ \\
Instar 2 & $268.67 \pm 29.72 \mathrm{a}$ & $224.00 \pm 17.90 \mathrm{a}$ \\
Instar 3 & $267.67 \pm 29.04 \mathrm{a}$ & $224.00 \pm 17.90 \mathrm{a}$ \\
Instar 4 & $259.33 \pm 25.17 \mathrm{a}$ & $219.67 \pm 13.69 \mathrm{a}$ \\
Instar 5 & $256.33 \pm 23.73 \mathrm{a}$ & $219.33 \pm 13.37 \mathrm{a}$ \\
Number of Adult & & \\
Emergence & $254.67 \pm 23.51 \mathrm{a}(89 \%)$ & $219.33 \pm 13.37 \mathrm{a}(97 \%)$ \\
Brachypterous & $122.33 \pm 8.67 \mathrm{a}$ & $106.33 \pm 4.91 \mathrm{a}$ \\
Macropterous & $132.33 \pm 14.95 \mathrm{a}$ & $112.00 \pm 14.11 \mathrm{a}$ \\
\hline
\end{tabular}

Means \pm SE followed by different letter for each row were significantly different according to independent t-test $(\mathrm{P}=0.05)$. F0 population $=10$ pairs of brachypterous adults. 
longevity were similar than those in Ketan Lusi (48 males and 8.2 days $)(\mathrm{t}=3.370, \mathrm{df}=4, \mathrm{P}=0.028 ; \mathrm{t}$ $=1.907, \mathrm{df}=8, \mathrm{P}=0.093$, respectively) (Table 2 and 3). Furthermore, IR64 (76.33 females and 7 days) also produced the female adults of brachypterous and their longevity was similat than that in Ketan Lusi (56.67 females and 8 days) $(\mathrm{t}=1.460, \mathrm{df}=4$, $\mathrm{P}=0.218 ; \mathrm{t}=-0.263, \mathrm{df}=8, \mathrm{P}=0.799$, respectively) (Table 2 and 3). In addition to that, the female adults of macropterous fed by Ketan Lusi (64 females) was similar than those in IR64 (40 females) $(\mathrm{t}=-2.176$, $\mathrm{df}=4, \mathrm{P}=0.95$ ) (Table 2). This result might be due to the quantity of tannin in Ketan Lusi was higher than that in IR64. This finding was with Al-Mehmadi and Al-Khalaf (2010) on different species Culex quinquefasciatus reported that the crude extract of
Melia azedarach contain tannins was effective against third instar larvae of C. quinquefasciatus. The variety of toxicity was depending on the concentration and period of exposure. Furthermore, Schoonhoven et al. (2005) also reported that the chemical compound, especially tannin, reducing palatability level (feeding selectivity) was caused by the astrigent in which inhibite the process of feeding, reduce the weight, and change the biology and nutrition composition of the insect.

\section{Effect of Population Density on the Migration of Nilaparvata lugens}

Fecundity of Nilaparvata lugens. The eggs produced by $N$. lugens in IR64 (435 eggs) was similar those in Ketan Lusi (409.33 eggs) $(t=0.376, d f=4$,

Table 2. The emergences number of male and female of Nilaparvata lugens fed using resistant and susceptible varieties without adding five males of macropterous on $\mathrm{F} 0$ population

\begin{tabular}{lcc}
\hline Parameter & \multicolumn{2}{c}{ Variety } \\
\cline { 2 - 3 } & IR64 & Ketan Lusi \\
\hline Number of adults & $92.23 \pm 12.20 \mathrm{~b}$ & $48.00 \pm 4.93 \mathrm{a}$ \\
O Macropterous & $46.00 \pm 12.34 \mathrm{a}$ & $49.67 \pm 3.52 \mathrm{a}$ \\
O Brachypterous & $138.33 \pm 20.16 \mathrm{a}$ & $97.67 \pm 1.85 \mathrm{a}$ \\
O & $40.00 \pm 4.51 \mathrm{a}$ & $64.00 \pm 10.06 \mathrm{a}$ \\
क Macropterous & $76.33 \pm 12.91 \mathrm{a}$ & $56.67 \pm 3.84 \mathrm{a}$ \\
क Brachypterous & $116.33 \pm 17.37 \mathrm{a}$ & $120.67 \pm 12.54 \mathrm{a}$ \\
क & 52.00 & 55.00 \\
Adult emergence (\%) & 52.00 & 51.50 \\
Macropterous (\%) & 48.00 & 48.50 \\
Brachypterous (\%) & &
\end{tabular}

Means \pm SE followed by different letter for each row were significantly different according to independent $\mathrm{t}$-test $(\mathrm{P}=0.05)$. F0 population $=10$ pairs of brachypterous adults.

Table 3. The life cycle of Nilaparvata lugens fed using resistant and susceptible varieties without adding five males of macropterous on F0 population

\begin{tabular}{lcr}
\hline Longevity (day) & \multicolumn{2}{c}{ Variety } \\
\cline { 2 - 3 } & \multicolumn{1}{c}{ IR64 } & Ketan Lusi \\
\hline Eggs & $3.20 \pm 0.20 \mathrm{a}$ & $3.20 \pm 0.13 \mathrm{a}$ \\
Nymph & & \\
$\quad$ Instar 1 & $9.00 \pm 0.00^{*}$ & $9.00 \pm 0.00^{*}$ \\
Instar 2 & $3.30 \pm 0.15 \mathrm{a}$ & $3.20 \pm 0.13 \mathrm{a}$ \\
Instar 3 & $2.70 \pm 0.15 \mathrm{a}$ & $2.80 \pm 0.13 \mathrm{a}$ \\
Instar 4 & $2.20 \pm 0.13 \mathrm{a}$ & $2.10 \pm 0.10 \mathrm{a}$ \\
Instar 5 & $2.30 \pm 0.15 \mathrm{a}$ & $2.50 \pm 0.17 \mathrm{a}$ \\
Longevity of nymph & $19.50 \pm 0.16 \mathrm{a}$ & $19.60 \pm 0.22 \mathrm{a}$ \\
Longevity of immature & $22.70 \pm 0.37 \mathrm{a}$ & $22.80 \pm 0.25 \mathrm{a}$ \\
Adult longevity & $15.20 \pm 1.80 \mathrm{a}$ & $8.20 \pm 3.20 \mathrm{a}$ \\
Male & $7.00 \pm 3.07 \mathrm{a}$ & $8.00 \pm 2.26 \mathrm{a}$ \\
Female & $25.90 \pm 0.43 \mathrm{a}$ & $26.00 \pm 0.25 \mathrm{a}$ \\
Life cycle & &
\end{tabular}

Means \pm SE followed by different letter for each row were significantly different according to independent $\mathrm{t}$-test $(\mathrm{P}=0.05)$. F0 population $=10$ pairs of brachypterous adults. $*$ Data was constant and could not be analyzed 
$\mathrm{P}=0.726$ ) (Table 4). That result might be due to the quantity of tannin in Ketan Lusi was higher than that in IR64. On the other hand, previous study (Park et al., 2004) on different host [sweet persimmon (cv. Fuyu) dan Astringent (cv. Chongdosi)] and different species (Riptortus clavatus) showed that the higher quantity of tanning, the more decrease of the eggs produced.

The life cycle of Nilaparvata lugens. The nymphs produced and adults emerged of $N$. lugens fed by IR64 was similar with in Ketan Lusi $(\mathrm{t}=0.996$, $\mathrm{df}$ $=4, \mathrm{P}=0.376$ ) (Table 4). This result might be due to $N$. lugens adapted to IR64 and Ketan Lusi. Previous research (Hao et al., 2008) reported that the digesting process of the phloem fluid absorbed by $N$. lugens was shorter in resistant gene (resistant variety) than the susceptible gene (susceptible variety).
The number and longevity of male adults of $N$. lugens macropterous on migration population fed using IR64 (70 males and 12.6 days) was higher and longer than those fed on Ketan Lusi (53.67 males and 4.2 days $)(\mathrm{t}=1.952, \mathrm{df}=4, \mathrm{P}=0.123 ; \mathrm{t}=4.099$, $\mathrm{df}=8, \mathrm{P}=0.003$, respectively) (Table 5 and 6). Those results might be due to by the low quantity of tannin in IR64, thus the nutrients were absorbed optimally than that in Ketan Lusi. Furthermore, the number and longevity of female adults of $N$. lugens brachypterous on migration population fed using IR64 (69.33 females and 11.2 days) was relatively same than those fed on Ketan Lusi (55 males and 5.2 days) $(\mathrm{t}=1.502, \mathrm{df}=4, \mathrm{P}=0.208 ; \mathrm{t}=2.179$, $\mathrm{df}$ $=8, \mathrm{P}=0.061$, respectively) (Table 5 and 6 ). The quality of IR64 might be more suitable for F1 offspring of $N$. lugens to grow and to develop than that in Ketan Lusi. This results was supported by $\mathrm{Lu}$

Table 4. The number of eggs, nymphs and F1 adults of Nilaparvata lugens fed using resistant and susceptible varieties with adding five males of macropterous on F0 population

\begin{tabular}{lcc}
\hline Parameter & \multicolumn{2}{c}{ Variety } \\
\cline { 2 - 3 } & IR64 & Ketan Lusi \\
\hline Number of eggs & $435.00 \pm 42.00 \mathrm{a}$ & $409.33 \pm 53.73 \mathrm{a}$ \\
Number of nymph & $244.67 \pm 25.10 \mathrm{a}$ & $219.00 \pm 5.85 \mathrm{a}$ \\
Instar 1 & $244.67 \pm 25.10 \mathrm{a}$ & $219.00 \pm 5.85 \mathrm{a}$ \\
Instar 2 & $244.33 \pm 24.77 \mathrm{a}$ & $219.00 \pm 5.86 \mathrm{a}$ \\
Instar 3 & $244.33 \pm 24.77 \mathrm{a}$ & $218.67 \pm 5.56 \mathrm{a}$ \\
Instar 4 & $244.33 \pm 24.77 \mathrm{a}$ & $216.00 \pm 3.20 \mathrm{a}$ \\
Instar 5 & & \\
Number of Adult & $244.33 \pm 24.77 \mathrm{a}(99.8 \%)$ & $216.00 \pm 3.21 \mathrm{a}(98.6 \%)$ \\
Emergence & $120.00 \pm 10.69 \mathrm{a}$ & $107.00 \pm 1.53 \mathrm{a}$ \\
Brachypterous & $122.00 \pm 14.19 \mathrm{a}$ & $118.67 \pm 12.99 \mathrm{a}$ \\
Macropterous & &
\end{tabular}

Means \pm SE followed by different letter for each row were significantly different according to independent $t$-test $(\mathrm{P}=0.05)$. Five males of macropterous was added in F0 population (10 pairs of brachypterous) on fifth day after first infestation.

Table 5. The emergences number of male and female of Nilaparvata lugens fed using resistant and susceptible varieties with adding five males of macropterous on F0 population

\begin{tabular}{|c|c|c|}
\hline \multirow[t]{2}{*}{ Parameter } & \multicolumn{2}{|c|}{ Variety } \\
\hline & IR64 & Ketan Lusi \\
\hline \multicolumn{3}{|l|}{ Number of adults } \\
\hline ऽ Macropterous & $70.33 \pm 8.29 a$ & $53.67 \pm 2.03 a$ \\
\hline Brachypterous & $50.67 \pm 4.37 \mathrm{a}$ & $52.00 \pm 2.31 \mathrm{a}$ \\
\hline 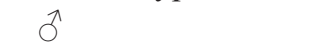 & $121.00 \pm 12.53 \mathrm{a}$ & $105.67 \pm 4.33 \mathrm{a}$ \\
\hline q Macropterous & $53.67 \pm 9.56 \mathrm{a}$ & $65.00 \pm 12.53 \mathrm{a}$ \\
\hline$q$ Brachypterous & $69.33 \pm 9.06 \mathrm{a}$ & $55.00 \pm 3.00 \mathrm{a}$ \\
\hline q & $123.00 \pm 18.52 \mathrm{a}$ & $120.00 \pm 11.14 \mathrm{a}$ \\
\hline Adult emergence $(\%)$ & 56.00 & 52.80 \\
\hline Macropterous (\%) & 51.00 & 51.00 \\
\hline Brachypterous (\%) & 49.00 & 49.00 \\
\hline
\end{tabular}

Means \pm SE followed by different letter for each row were significantly different according to independent t-test $(\mathrm{P}=0.05)$. Five males of macropterous was added in F0 population (10 pairs of brachypterous) on fifth day after first infestation. 
Table 6. The life cycle of Nilaparvata lugens fed using resistant and susceptible varieties with adding five males of macropterous on $\mathrm{F} 0$ population

\begin{tabular}{lcr}
\hline Longevity (day) & \multicolumn{2}{c}{ Variety } \\
\cline { 2 - 3 } & \multicolumn{1}{c}{ IR64 } & Ketan Lusi \\
\hline Eggs & $4.00 \pm 0.00^{*}$ & $3.00 \pm 0.00^{*}$ \\
Nymph & $7.00 \pm 0.00^{*}$ & \\
Instar 1 & $3.20 \pm 0.13 \mathrm{a}$ & $8.00 \pm 0.00^{*}$ \\
Instar 2 & $2.90 \pm 0.10 \mathrm{a}$ & $4.00 \pm 0.00 \mathrm{~b}$ \\
Instar 3 & $2.70 \pm 0.26 \mathrm{a}$ & $2.30 \pm 0.26 \mathrm{a}$ \\
Instar 4 & $2.10 \pm 0.10 \mathrm{~b}$ & $2.30 \pm 0.15 \mathrm{a}$ \\
Instar 5 & $17.90 \pm 0.31 \mathrm{a}$ & $3.20 \pm 0.35 \mathrm{a}$ \\
Longevity of nymph & $21.90 \pm 0.41 \mathrm{a}$ & $19.80 \pm 0.57 \mathrm{~b}$ \\
Longevity of immature & & $22.80 \pm 0.33 \mathrm{~b}$ \\
Adult longevity & $12.60 \pm 1.86 \mathrm{a}$ & \\
Male & $11.20 \pm 2.65 \mathrm{a}$ & $4.20 \pm 0.86 \mathrm{~b}$ \\
Female & $25.90 \pm 0.41 \mathrm{a}$ & $5.20 \pm 0.73 \mathrm{a}$ \\
Life cycle & & $25.80 \pm 0.33 \mathrm{a}$ \\
\hline
\end{tabular}

Means \pm SE followed by different letter for each row were significantly different according to independent $t$-test $(\mathrm{P}=0.05)$. Five males of macropterous was added in F0 population (10 pairs of brachypterous) on fifth day after first infestation. *Data was constant and could not be analyzed

et al. (2007) and Chandramani et al. (2009) stated that the quality of host suitability on the fitness of major insect pest in rice was related to the physical, chemical, and the nutrient composition of the host plant, and that the use of pesticide with the quantity of tannin of 5.65 and $4.5 \mathrm{mg} / \mathrm{g}$ produced the adult longevity of 5 to 7.15 days. In addition to that, the percentage of nymphs become adults in IR64 (99.8 \%) was similar with Ketan Lusi (98.6 \%) (Table 4) Those results described above showed that the population density and the existing of resistant variety (IR64) increased the percentage of the $N$. lugens nymphs become adults than those fed in susceptible variety (Ketan Lusi). Percentage of adults that increased of $52 \%$ to $56 \%$ in higher population triggered those to migrate. Similar finding was reported by Ritberg and Isman (1992) stated that the population density effects the behaviour of the insect. In addition to that, Khaliq et al. (2014) also stated that the response of increase in population density may decrease their rate of increase. Another best example of crowding is Tribolium castaneum in which density dependent effect is positively correlated with the adult emergence on the floor surface. Furthermore, Washburn et al. (1985) reported that the body size and fecundity of Pulvinariella mesembryanthemi were related to their density population, in which indicating the existing of intraspecific competition.

\section{CONCLUSION}

The existing of the macropterous adult (migrated population) did not effect the formation of the macropterous, both in susceptible and resistant varieties.
Because of the the percentage of existing macropterous in both varieties was similar (51 and 52\%), before and after the adding of five males macropterous. This result showed that the formation of the macropterous adult has already been planned by F0 and the existing of that insect migration did not effect their offspring.

\section{ACKNOWLEDGMENT}

We would like to thank to Directorate of Education (DIKTI) for partial funding to conduct this study; the farmers in Jaten Village, Juwiring County, Klaten District, Central Java Province, Indonesia for their help to provide the $N$. lugens before they sprayed the insecticide; and Teguh Rahayu for assistance in discussion to complete this manuscript.

\section{LITERATURE CITED}

Asikin, S. 2006. Rice Stem Borer Control With Trap Plants and Materials Ameliorasi Tidal Land. Reports of Research. Balittra. Banjarbaru.

Al-Mehmadi, R.M., \& A.A. Al-Khalaf. 2010. Larvacidal and Histological Effects of Melia azedarach Extract on Culex quinquefasciatus Say Larvae (Diptera: Culicidae). Journal of King Saud University (Science) 22: $77-85$.

Bale, J.S, G.J. Masters, I.D. Hodkinson, C. Awmack, T.M. Bezemer, V.K. Brown, J. Butterfield, A. Buse, J.C. Coulson, \& J. Farrar. 2002. Herbivory in Global Climate Change Research: Direct Effects of Rising Temperature on Insect Herbivores. Global Change Biology 8: 1-16. 
Cannon, R.J.C. 1998. The Implications of Predicted Climate Change for Insect for Insect Pests in the UL, with Emphasis on Non-Indigenous Species, Global Change Biology 4: 785-796.

Chandramani, P., R. Rajendran, P. Sivasubramanian, \& C. Muthiah. 2009. Management of Hoppers in Rice through Host Nutrition: A Novel Approach. Journal of Biopesticides 2: 99-106.

Cholifa, S. 2011. Evaluation of Sustainability of Same Strains of Catton (Gossypium hirsutum L.) to the Fruit Borer (Helicoverpa armigera Hbn.) [Evaluasi Ketahanan Beberapa Galur Kapas (Gossypium hirsutum L.) terhadap Penggerek Buah (Helicoverpa armigera Hbn.)]. Bachelor Thesis. Departement of Biology, Universitas Islam Negeri Maulana Malik Ibrahim, Malang. 59 p.

Debby, D.M. \& M. Moniharapon. 2014. Antifeedant Activity of Ethanol Extract of Melinjo Leaves (Gnetum gnemon L.) against Oriental Leafworm Moth (Spodoptera litura Fab.) on Cabbage (Brassica sinensis L.). Jurnal Budidaya Pertanian 10: 100-104.

Hao, P., C. Liu, Y. Wang, R. Chen, M. Tang, B. Du, L. Zhu, \& G. He. 2008. Herbivore-Induced Callose Deposition on the Sieve Plates of Rice: An Important Mechanism for Host Resistance. Plant Physiology 146: 1810-1818.

Khaliq, A., M. Javed, M. Sohail, \& M. Sagheer. 2014. Environmental Effect on Insects and their Population Dynamics. Journal of Entomology and Zoology Studies 2: 1-7.

Lu, Z.X., X.P. Yu, L.H. Kong, \& H. Cui. 2007. Effect of Nitrogen Fertilizer on Herbivores and its Stimulation to Major Insect Pests in Rice. Journal Rice Science 14: 56-66.

Mbata, G.N., T.W. Phillips, \& M.E. Payton. 2009. Effects of Cowpea Varietal Susceptibility and Low Pressure on Mortality of Life Stage of Callosobruchus maculatus (Coleoptera: Bruchidae). Journal of Stored Products Research 45: 232-235.

Nurbaeti, B., I.G.P.A. Diratmaja, \& S. Putra. 2010. Brown Planthoppers (Nilaparvata lugens Stal.). West Java Assessment Institute for Agricultural Technology. Ministry of Agriculture, Jakarta. 24 p.
Park, C.G., K.C. Lee, D.W. Lee, H.Y. Choo, \& P.J. Albert. 2004. Effects of Purified Persimmon Tannin and Tannic Acid on Survival and Reproduction of Bean Bug, Riptortus clavatus. Journal of Chemical Ecology 11: 2269-2283.

Schoonhoven, L.M., J. J.A.V. Loon, \& M. Dicke 2005. Plants as Insect Food: not the Ideal. Second edition. Oxford University Press, New York. 120 p.

Sembiring, H. 2015. Program Implementation of Application Movement of Integrated Crop Management (GP-PTT) Rice 2015 [Pedoman Teknis Gerakan Penerapan Pengelolaan Tanaman Terpadu (GP-PTT) Padi 2015]. Directorate of Food, Ministry of Agriculture, Jakarta. 100 p.

Serratos, A., J.T. Amason, C. Nozzolillo, J.D.H. Lambert, B.J.R. Philogene, G. Fulcher, K. Davidson, L. Peacock, J. Atkinson, \& P. Morand. 1987. Factor Contributing to Resistance of Exotic Maize Populations to Maize Weevil, Sitophilus zeamais. Journal of Chemical Ecology 3: 751-762.

Trumble, J.T. \& J.D. Hare. 1997. Tritrophipc Interactions in the Management of Spodoptera exigua and Other Pests on Celery, p. 117-134. In K. Bonderi (ed.), Recent Developments in Entomology. Research Signpost, Trivandrum, India,

Wardani, R. \& R. Khatir. 2011. Characteristics Drying Rice Flour Using Equipment Dryer Rack Type. Jurnal Ilmiah Pendidikan Biologi, Biologi Edukasi 3: 1-4.

Waspo, A. 1999. Indonesia Food Production in 1998, Writhing between Drought and Flooded. Wacana 15 (Special Edition): 10-12.

Washburn, J. O., \& K. C. Frankie. 1992. Role of Ants in Pest Management. Annual Review of Entomology 37: 479-503.

Zhang, W., X. Q. Chang, A. A. Hoffmann, S. Zhang, \& C.S. Ma. Impact of Hot Events at Differenct developmental stages of a Moth: The Closer to Adult Stage, The Less Reproductive Output. Scientific Report 5: 1-9. 